\title{
Mineralogy and technology of bricks used for the construction of the XII century ducal castle on the island of Ostrów Tumski, Wrocław (SW Poland)
}

\author{
W. Bartz* , M. Chorowska** \\ W. Bartz: University of Wrocław; Institute of Geological Sciences pl. M. Borna 9; 50-204 Wrocław \\ M. Chorowska: Technical University of Wrocław, Faculty of Architecture; Wybrzeże Wyspiańskiego 27; 50-370 Wrocław
}

Record

Historic bricks used for the construction of the XII century ducal castle on the island of Ostrów Tumski record the conditions of firing and allow for the identification of different construction phases.

Abstract

The historic bricks from the ducal castle on Ostrów Tumski (Wrocław), one of the first brickwork structures in the Lower Silesia, which dates back to the XII and XIII century, were studied and characterised by a combination of classical petrographic studies (polarising microscopy), scanning microscopy, thermal analysis and X-ray diffraction. The combined results of these methods suggest that the firing temperature ranges from $950^{\circ} \mathrm{C}$, through the most common temperatures of $850-900^{\circ} \mathrm{C}$, to the infrequent temperatures below $750^{\circ} \mathrm{C}$. Most of the bricks were fired under oxidising conditions, occasionally over a sequence of oxidising and reducing steps, resulting in a sandwich structure. The results indicate, that low-calcareous raw materials were used, presumably Miocene-Pliocene 'flamy clays', exploited a few kilometres away from the castle and tempered with locally obtained sand from the Odra river. Only small differences have been recognized in: 1) clay to aplastic material ratio, 2) amount of accessory minerals, 3) grain-size distribution of aplastic materials, but no significant changes in the brick technology were observed. The observed variability corresponds well to the different constructing phases, identified previously on the basis of archaeological work. Thus, our work proves that a detailed mineralogical and petrological study may help to identify different construction phases in historic monuments.

\section{Introduction}

The recognition of the historic constructing materials and constructive technology plays an essential role in their conservation and proper restoration. However, it is not an easy task, since ancient buildings are characterised by a complex history, obscured by multiple and overlapping reconstructions and renovations. Barluenga et al., (2014) are of an opinion that in order to fully recognise the complicated history of masonry, we should investigate its morphology, for example, by the means of statistical analysis of brick dimensions (Caban, 2015), or through a detailed study of the materials used. The latter might be realised through the application of mineralogical methods (Scalenghe et al., 2015; López-Arce et al., 2003). Hence, we decided to adapt this particular approach and try to recognise the history written down in the ducal castle located on the island of Ostrów Tumski. It is the oldest, and, from the historical and archaeological point of view, the most valuable building among the numerous monuments in Wrocław. Despite the fact, that only the remnants located below ground level survived to the present day (Małachowicz, 1994), they are the sole source of knowledge about the history of the
Keywords

applied mineralogy $\cdot$ historic bricks • firing technology $•$ castle $\cdot$ Ostrów Tumski

Received: 30 October 2015 Accepted: 10 December 2015

ducal castle in Wrocław. Since the XI century, it was an important fortified settlement and a residence of the Silesian Piast dukes. The history of the castle was mostly recorded by Małachowicz (1994). This data, although subjected to strong criticism (Grzybkowski, 1994; Żurek, 1996), have been widely accepted by the scientific community. However, the results of our archaeological research, conducted in the years 2011-2012, shed a new light on the history of the castle, its prosperity and slow fall into decline. Moreover, some of the concepts proposed previously by Małachowicz (1994) underwent an archaeological verification, but some of them needed to be altered. It was the result of, among other things, the numerous conversion of the castle and the lack of continuity of the archaeological layers. Therefore, bearing in mind the aforementioned statement, the aim of our study was diverse. Firstly, a detailed mineralogical analysis of the historic bricks sampled from different constructing phases of the castle and distinguished on the basis of archaeological work, was one important aim. We also tried to gather information about the raw materials used for the brick production and to assess the temperature of firing. Secondly, we wanted to compare the obtained results with the existing state of knowledge and, last but
*E-mail:wojciech.bartz@uwr.edu.pl

**E-mail:malgorzata.chorowska@pwr.edu.pl (c) BY-NC-ND $(2016$ W. Bartz, M. Chorowska, published by De Gruyter Open.

This work is licensed under the Creative Commons Attribution-NonCommercial-NoDerivs 3.0 License. 


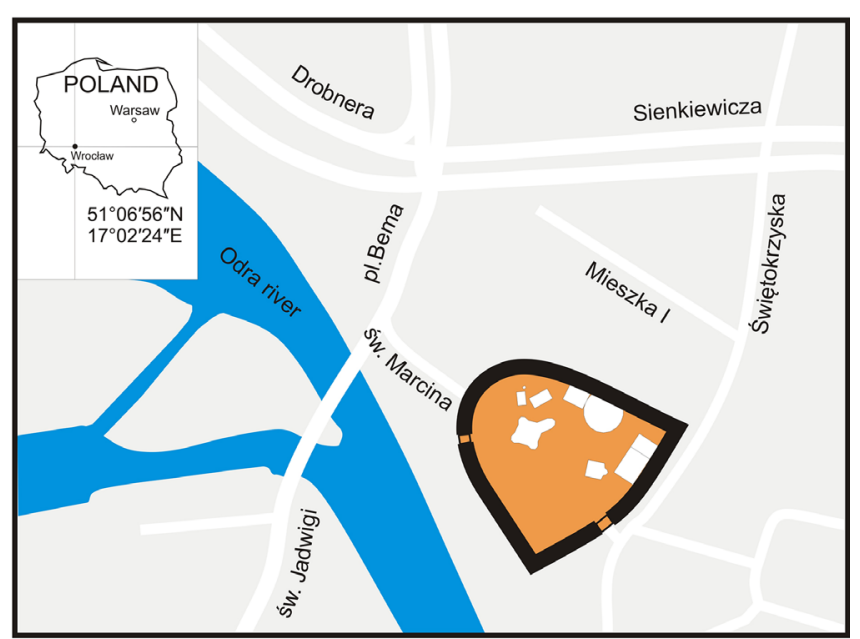

Figure 1. The location of the ducal castle on the island of Ostrów Tumski and the present-day street layout of Wrocław.

not least, we tried to gain further knowledge about the building history of the ducal castle on Ostrów Tumski. Finally, we expected that our research will help us assign the individual and undated relics to particular construction phases.

\section{Historical Notes}

The ducal castle in Wrocław was presumably built in 1175, in the place of a former stronghold Małachowicz (1994). The castle was situated on a river island called Ostrów Tumski (Figure 1). Unfortunately, despite the fact, that the castle was a huge brick structure, only relics of the underground part are preserved to this day (Figure 2). The current knowledge leads to a conclusion, that the castle underwent seven reconstruction phases in a relatively short period of time, starting at the end of the XII century and ending in the late XIII century. During the first, and the oldest construction phase (late XII century), an octadecogonal brick building (cylinder) was erected (Figure 3). It was a residential castle of the Duke Boleslaus I the Tall. Soon after, at the turn of the XII century, an elongated, so-called two-part building (Małachowicz \& Lasota, 1989) was erected, and the whole structure was flanked from the north-east with a ring-shaped curtain wall. Additionally, a corner-tower was built in two phases. During the reign of Duke Henry I Bearded (1201-1238), the octadecagonal building was partially demolished and replaced with a residential building, the so-called brick palace or the 'first palace' (Figure 3) with the length of more than $40 \mathrm{~m}$ and an adjacent palatine chapel. In the mid XII century, during the reign of Duke Henry III the White, the castle was surrounded by a fortified wall (Figure 3), polygonal in shape, entirely encircling the ducal residence. Fragments of the wall, erected in the south and the east of the castle, were built on brick pillars fastened with arcades. The largest reconstruction of the castle occurred during the reign of Henry IV Probus. In the

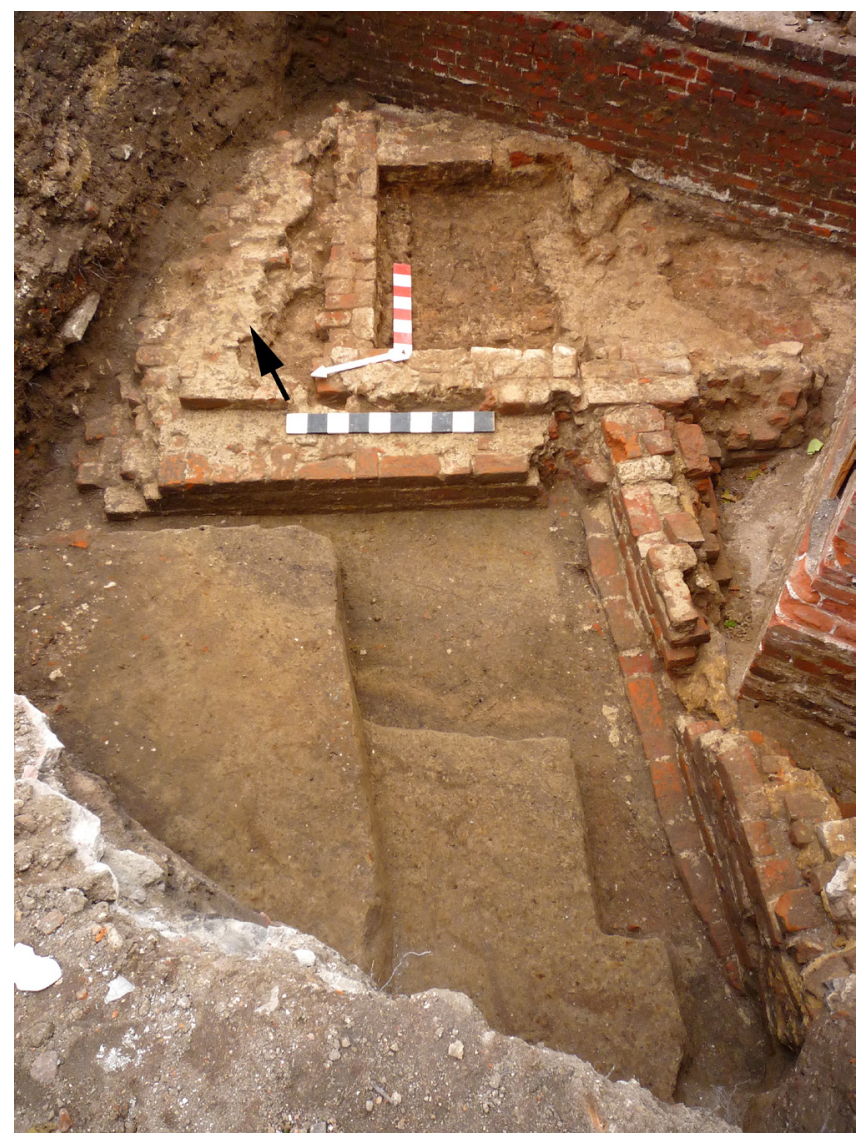

Figure 2. An example of the archaeological excavation showing remnants of the octagonal building.

80 's of the XIII century, the brick palace was rebuilt and replaced with a new one (Figure 3). The new palace (the so-called 'second palace') was located in the place of the demolished octadecagonal building and the curtain wall. It had the length of $50 \mathrm{~m}$ and included a distinct octagonal hall. The ducal castle on Ostrów Tumski was an important residence of the dukes, but in the 30's of the XIV century a new castle was built on the left bank of the river, close to the city. Firstly, the abandoned ducal castle was occupied by the clergy of the Collegiate Church of St. Cross. Soon after the death of Henry IV Probus, the ducal castle lost its importance. His successors, Henry V the Fat, Bolko I the Strict and Henry VI the Good, usually resided in the new castle situated on the left bank of the Oder river. In 1310, the ducal castle was partly passed on to the diocese. In 1345, a considerable part of the castle area was divided into parcels for canons. The redundant castle was demolished at the turn of the XV century.

\section{Sampling and Methods of Investigation}

Sampling was performed at the remnants of the castle during archaeological excavation in 2011-2012. A total of 39 samples was 


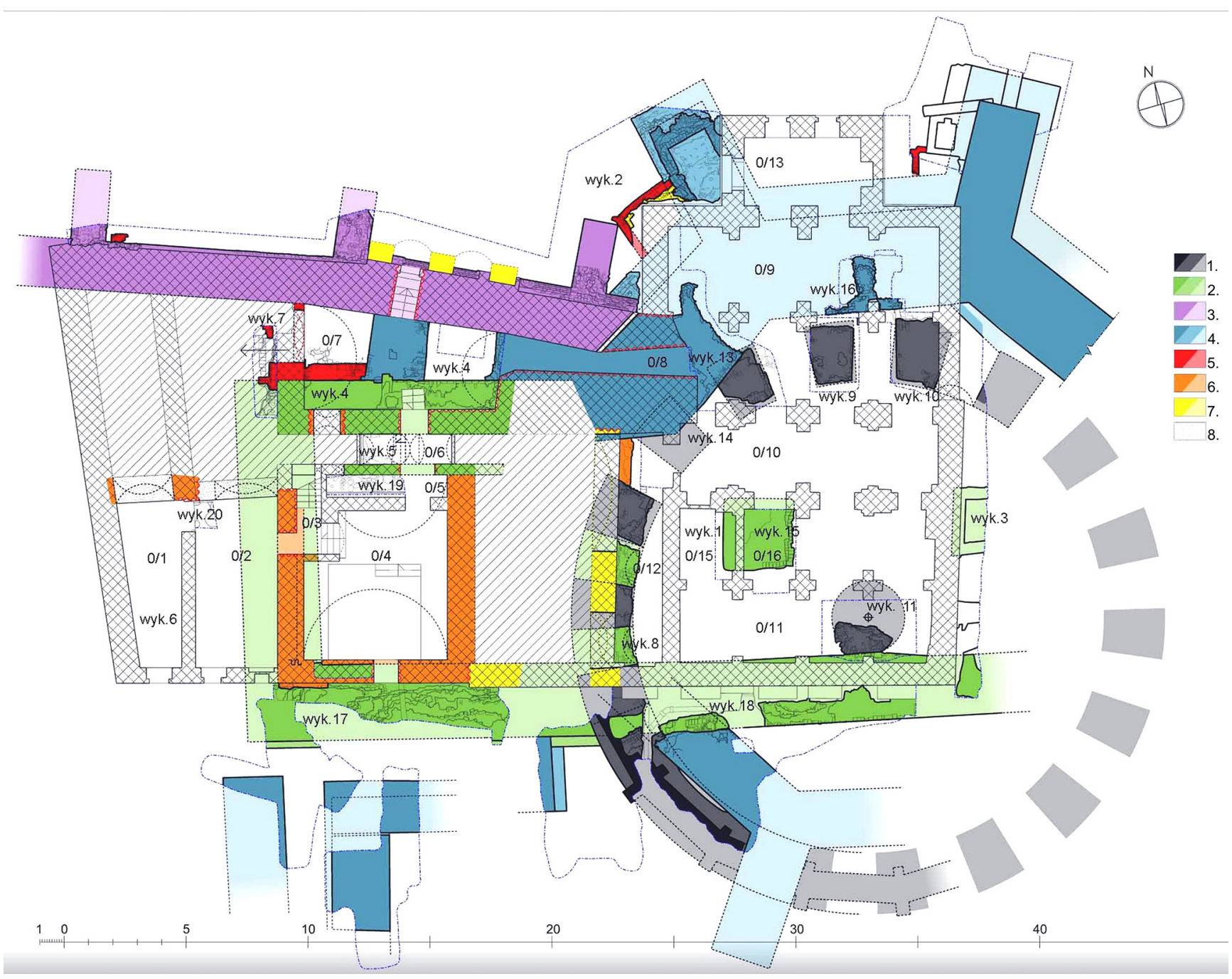

Figure 3. Sketch of the ducal castle on Ostrów Tumski with marked constructing phases. 1. 1166-1199; 2. 1175-1199; 3. turn of XII and XIII century; 4. 12001233; 5. mid XIII century, 6. 1266-1299; 7. 1275-1299; 8. 1400-1450; 9. 1450-1499. Drawing made by M. Caban.

collected and, after field observation, 16 representative bricks were chosen for a detailed mineralogical and petrological study. The location of the samples is summarised in Table 1.

The mineralogical analysis of the archaeological samples was carried out using several methods. Polarised optical microscopy and scanning electron microscopy combined with energy dispersive spectrometry (SEM-EDS) were applied in order to obtain information on the type of temper, the structure of the brick, the degree of porosity, and vitrification and chemistry of the clay matrix. Sample preparation consisted of cutting bricks into thin slices, perpendicular to the ceramic walls and polishing them to obtain standard petrographic thin sections with the thickness of 30-35 $\mu \mathrm{m}$. Subsequently, the prepared thin sections were examined at the Institute of Geological Sciences, University of Wroclaw, with the use of Zeiss Axiolab polarising microscope with a Canon G3 digital camera attached to it. Freshly fractured pieces of bricks coated with carbon were examined with the use of the scanning electron microscope (Vega LSU Tescan; $20 \mathrm{kV}$ accelerating voltage) equipped with RTG EDS INCA Penta-FETx3 Oxford Instruments, at Laboratory for Technological and Conservation Research, Wrocław University of Technology. The JMicroVision (Roduit, 2007) freeware was applied on digital photos of thin-sections, taken for the estimation of grain-size distribution. All grains, cross-cut by parallel lines (at each $1.5 \mathrm{~mm}$ ), were measured by the estimation of their equivalent diameter. At least one thousand grains were measured per one sample (thin section). The volume percentage composition and the proportion of the clay matrix and the aplastic material, were evaluated through the point-counting method, using the same JMicroVision software. Thermal analysis (differential scanning calorimetry-thermogravimetry DSC-TGA) and powder X-ray diffraction (PXRD) were used to determine the mineralogy of bricks, and to assess the firing temperature. 
Table 1. Details of the studied samples.

\begin{tabular}{l|l}
\hline Sample & \\
\hline WZ01 & excavation no. 8, the dodecagonal building, pillar no. 2 \\
\hline WZ02 & excavation no. 8, the dodecagonal building, pillar no. 1 \\
\hline WZ03 & excavation no. 11, the dodecagonal building, central pillar \\
\hline WZ04 & excavation no. 9, the dodecagonal building, pillar no. 5 \\
\hline WZ11 & excavation no. 3, southern wall of the brick palace \\
\hline WZ12 & excavation no. 3, southern wall of the brick palace \\
\hline WZ17 & excavation no. 8, brick palace, space between pillars \\
\hline WZ18 & excavation no. 8, brick palace, space between pillars \\
\hline WZ21 & excavation no. 2, the fortified wall, foundation of western buttress \\
\hline WZ22 & excavation no. 2, the fortified wall, foundation of western buttress \\
\hline WZ23 & excavation no. 2, the fortified wall, foundation of western buttress \\
\hline WZ24 & excavation no. 2, the fortified wall, foundation of western buttress \\
\hline WZ32 & $\begin{array}{l}\text { excavation no. 2 (northern), the octagonal hall, north-western buttress, } \\
\text { (outer part) }\end{array}$ \\
\hline WZ33 & $\begin{array}{l}\text { excavation no. } 3 \text { (eastern), the octagonal, basement of north-eastern } \\
\text { wall }\end{array}$ \\
\hline excavation no. 3 (eastern), the octagonal, arch \\
\hline excavation no. 2 (northern), the octagonal, north-western buttress \\
\hline inner part)
\end{tabular}

PXRD measurements were performed on pulverised samples in an agate mortar, using PANalytical EMPYREAN WAXS/SAXS X-ray diffractometer (CuKa radiation, 2 Theta range $5 \div 70$ deg.) at X-ray Cristallography Laboratory, EIT+ Wrocław Research Centre. DSCTGA scans were acquired at the Institute of Geological Sciences, University of Wroclaw, with the use of PerkinElmer STA6000, and were performed at 40 to $990^{\circ} \mathrm{C}$, at the heating rate of $10^{\circ} \mathrm{C} / \mathrm{min}$, in $\mathrm{N} 2$ atmosphere, with the flow of $15 \mathrm{~mL} / \mathrm{min}$. The sample mass varied between 30 and $40 \mathrm{mg}$.

\section{Results and Discussion}

\subsection{Microscopic observations}

Microscopic observations of brick slices cut perpendicular to their walls, revealed that individual samples differ from each other. First of all, the examined samples differ in colour and, to a lesser extent, in structure. Most of the bricks are homogenously coloured red-orange (Figure 5A, C, D; 6B, C; 7A, C, D), whereas brick-red (Figure 4A, C; 6D; 7B) or yellowish-beige (Figure 4D; $5 B)$, are less common. Bricks with a well-developed sandwichlike structure, that are heterogeneously coloured are uncommon (Figure 4B; 6A). Typical for the latter is a greyish-black core, surrounded by a red-orange (Figure $4 \mathrm{~B}$ ) or brick-red margin. Reverse zoning, that is, a reddish core and dark greyish margin (Figure 6A) is less common. In fact, some of the previously mentioned ho-
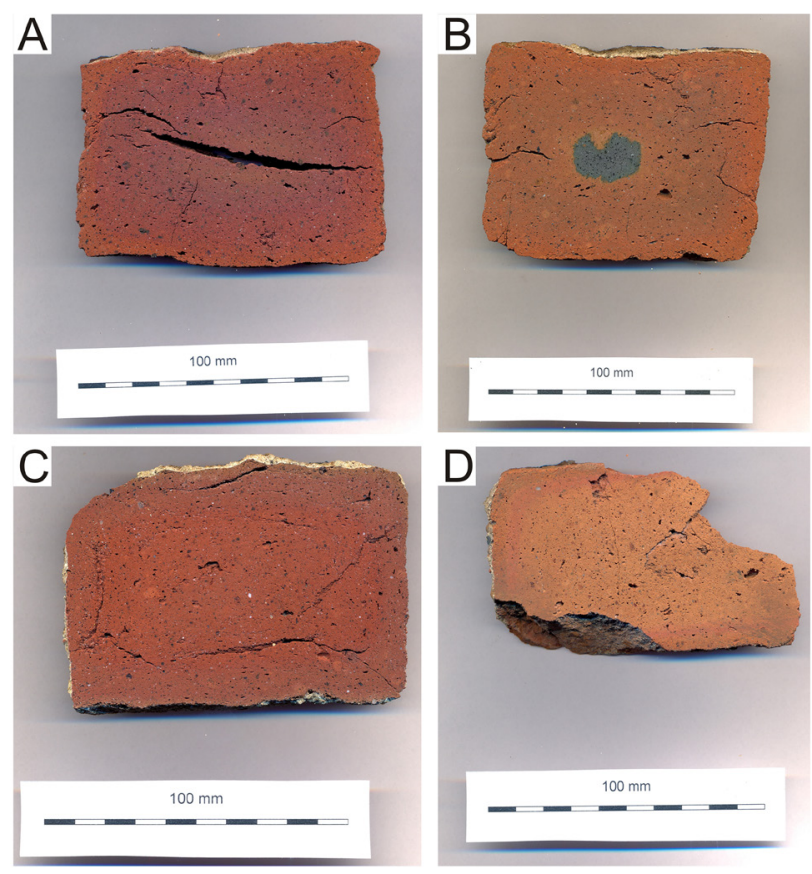

Figure 4. Cross-sections of examined bricks from the octadecagobal brick building (cylinder).
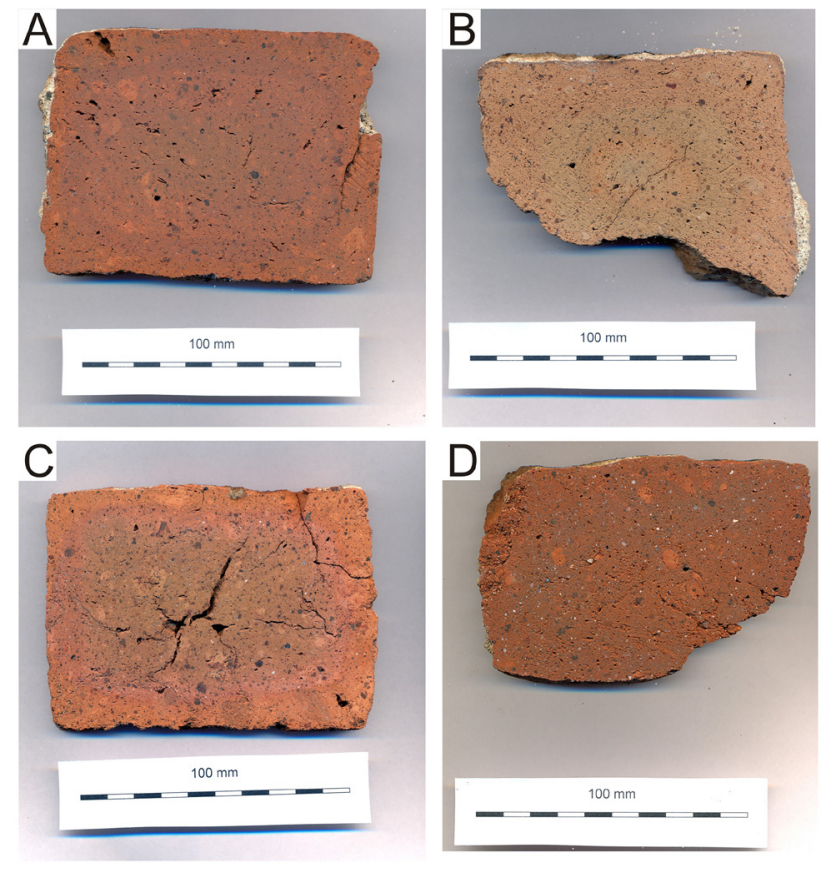

Figure 5. Cross-sections of examined bricks from the brick (first) palace.

mogenous bricks show very weak zoning too (Figure 4A; 5A; 7B). Moreover, there is a well-marked interdependence between the colour of the brick and its structure. Lighter bricks are hetero- 

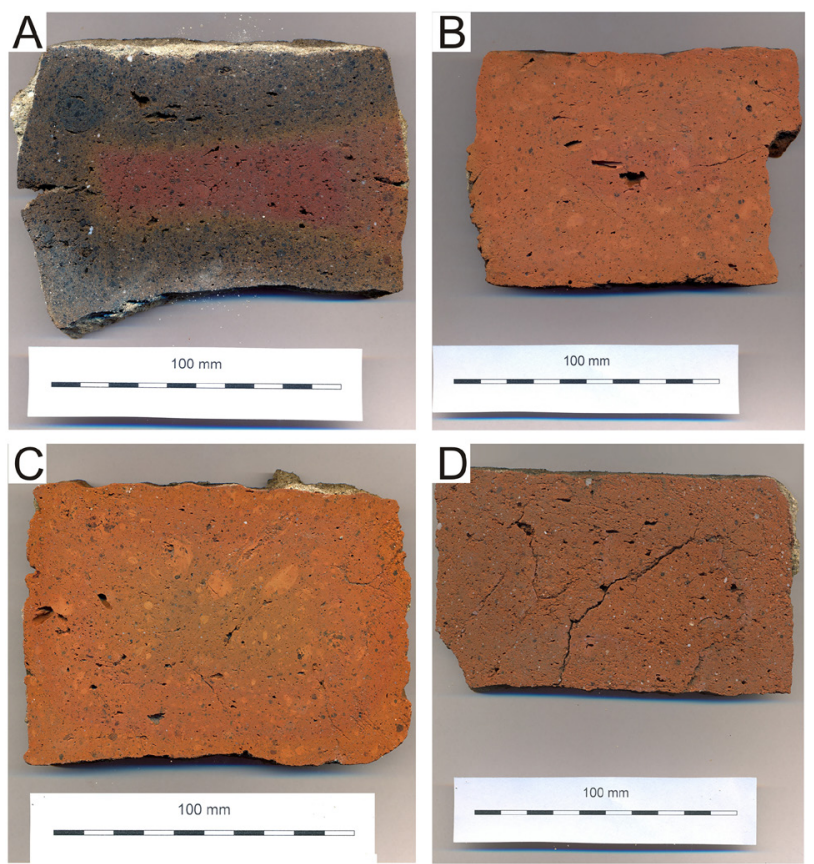

Figure 6. Cross-sections of examined bricks from the brick (first) palace.
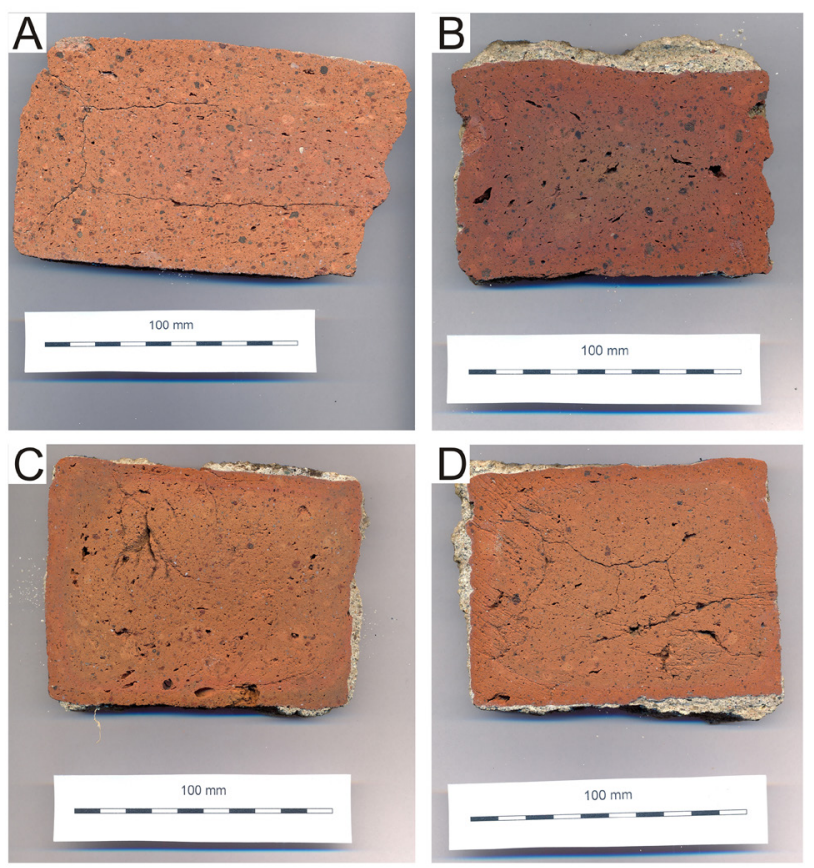

Figure 7. Cross-sections of examined bricks from the defensive wall.

geneous, containing well-visible clay lumps, less compact and strongly cracked, whereas darker bricks are usually more compact and better homogenised. At first glance, such differences
Table 2. Modal composition of studied bricks.

\begin{tabular}{l|c|c|c|c|c}
\hline \multirow{2}{*}{ Sample } & \multicolumn{5}{|c}{ Modal proportion [vol \%] } \\
\cline { 2 - 6 } & Quartz & Feldspars & Lithic grains & Accesories & Clay matrix \\
\hline WZ1 & 31.6 & 2.9 & 5.4 & 0.2 & 59.9 \\
\hline WZ2 & 26.4 & 4.1 & 6.4 & 0.9 & 62.2 \\
\hline WZ3 & 26.3 & 3.6 & 6.9 & 0.4 & 62.8 \\
\hline WZ4 & 31.1 & 3.3 & 7.1 & 1.0 & 57.5 \\
\hline & & & & & \\
\hline WZ11 & 17.0 & 3.2 & 3.3 & 1.3 & 75.2 \\
\hline WZ12 & 22.7 & 2.1 & 4.8 & 0.9 & 69.5 \\
\hline WZ17 & 24.0 & 2.9 & 6.4 & 1.4 & 65.3 \\
\hline WZ18 & 24.8 & 3.0 & 5.9 & 1.1 & 65.2 \\
\hline & & & & & \\
\hline WZ21 & 23.0 & 2.2 & 4.6 & 0.6 & 69.6 \\
\hline WZ22 & 25.4 & 1.9 & 5.2 & 0.3 & 67.2 \\
\hline WZ23 & 21.5 & 2.6 & 3.9 & 0.5 & 71.5 \\
\hline WZ24 & 26.0 & 3.1 & 5.0 & 0.7 & 65.2 \\
\hline & & & & & \\
\hline WZ32 & 29.6 & 3.9 & 5.7 & 0.3 & 60.5 \\
\hline WZ33 & 32.2 & 3.6 & 5.1 & 0.3 & 58.8 \\
\hline WZ34 & 31.5 & 3.8 & 4.8 & 0.8 & 59.1 \\
\hline WZ35 & 32.2 & 3.1 & 4.1 & 0.4 & 60.2 \\
\hline & & & & &
\end{tabular}

in the colour and structure of the ceramic could be attributed to the use of different raw materials. However, they indicate the differences in the firing procedure, i.e. the temperature of firing and the oxidising/reducing conditions in the kiln (Rathossi et al., 2004; Cardiano et al., 2004). Typically, darker colours are linked to a high temperature of firing and a more advanced vitrification of the clayey matrix, and vice versa (López-Arce et al., 2003). Thus, we can suspect that the reddish and more compact bricks resulted from a higher firing temperature, causing a greater degree of clayey matrix transformation, as compared to the yellowish-beige bricks, which were fired at relatively low temperatures. The most common, red-orange bricks, were formed at intermediate temperatures.

Some of the analysed bricks show colour changes in the single clay body. As will be discussed later in more detail, it cannot be attributed to the differences in composition. It is known, that multicoloured ceramic can be produced through a single firing process, but consisting of a sequence of oxidising and reducing steps (İssi et al., 2011). According to Maritan et al. (2006), this kind of colour differentiation results from the differences in mineral assemblages and the state of iron oxidation. In the sandwich-like structure, the black core contains iron in the form of $\mathrm{Fe}^{2+}$ in magnetite, whereas in the brick margin, this element occurs in the form of oxidised $\mathrm{Fe}^{3+}$ in hematite (Gredmaier et al., 2011). During firing, oxygen slowly diffuses into the clay body, whereas carbon monoxide and dioxide diffuse out of the clay body (Gredmaier et al., 2011). The proportion of the black core and the red margin depends mostly on: 1 ) the oxygen content in the atmosphere in the kiln; 2) the firing time - a longer firing time can eliminate 

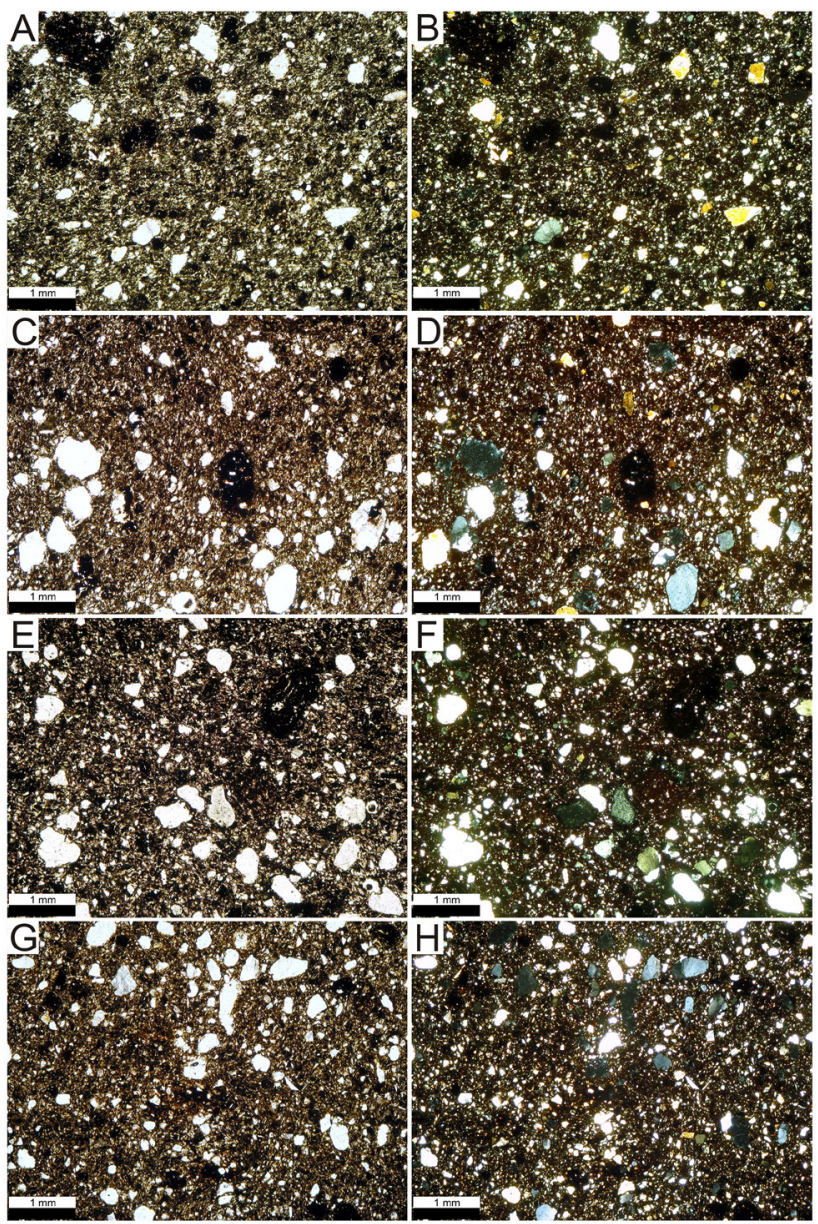

Figure 8. Microphotographs of bricks from the octadecagonal brick building (cylinder) in plane-polarised light (left column) and cross-polarised light (right column). Samples: A, B-WZ1; C, D-WZ2, E, F-WZ3, G, H-WZ4.

the black reduction core; 3) the iron and carbon content in the raw material (Gredmaier et al., 2011). Thus, the black core and the red margin of brick no. WZ2 (Figure 4B; Table 1), indicate a shorter residence time in the kiln and a lower oxygen content, as compared to homogenous bricks. Furthermore, the latter were fired longer, and in a more oxidising atmosphere. The observed reverse zoning (Figure 6A; Table 1) can be explained as the result of a two-step firing, initially under oxidising conditions and then, under reducing conditions.

The petrographic analysis shows, that bricks are composed of slightly birefringent clay matrices and numerous aplastic components (Figure 8-11). The colour of the matrices varies from yellowish-brown (Figure 9C), through orange-brown, reddishbrown (Figure 11A;8C), up to brownish-black (Figure 10A), in plane-polarised light. Typically, a dark-coloured matrix shows an undifferentiated fabric, with its components not distinguishable in the polarised light. Moreover, although the feldspar grains retain their shape, they exhibit altered optical properties. In
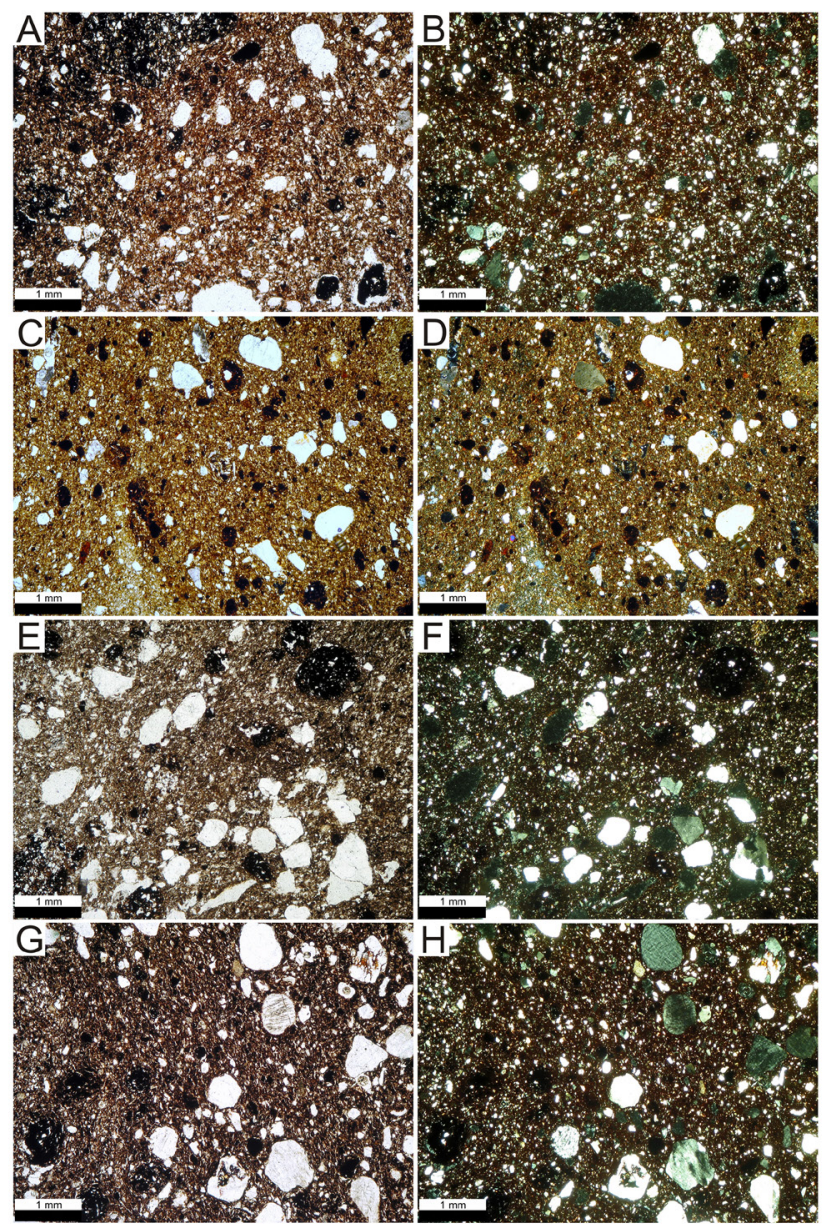

Figure 9. Microphotographs of bricks from the brick (first) palace in plane-polarised light (left column) and cross-polarised light (right column). Samples: A, B-WZ11; C, D-WZ12, E, F-WZ17, G, H-WZ18.

plane-polarised light, the feldspars attain a clouded appearance, become yellowish or brownish (Figure 10A); in cross-polarised light, they show a strongly decreased birefringence, or become optically isotropic (Figure 10B). SEM observations revealed, that the phyllosilicates tend to deform and clump together (Figure 12) due to local sintering among adjacent crystals. Vitrification was clearly observed in the sample WZ21 (Figure 13). In the case of light-coloured matrices, single flakes of clay minerals and/or their small aggregates were embedded in prevailing optically isotropic mass. Sample WZ12 (Figure 9C, D), yellowish-brown in plane-polarised light, is the only exception. The clayey micro-mass of this sample is highly birefringent, and randomly oriented clay minerals are well distinguishable. A relatively well-preserved clayey material of the paste is evidenced by the SEM observations, showing a maintained laminar character of the phyllosilicates, with no signs of vitrification or sintering.

The structures described above show, that almost all of the examined bricks were fired under a relatively high temperature, 


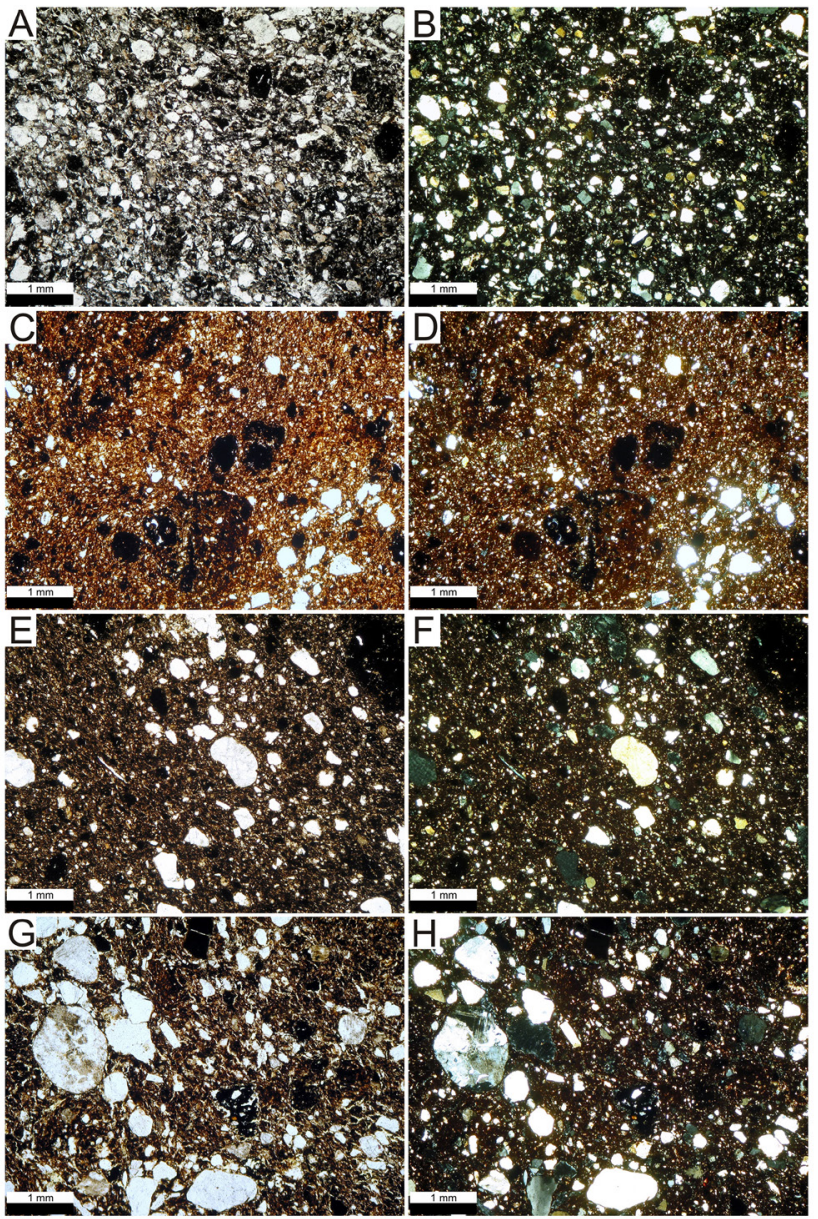

Figure 10. Microphotographs of bricks from the defensive wall, in plane-polarised light (left column) and cross-polarised light (right column). Samples: A, $B$-WZ21; C, D-WZ22, E, F-WZ23, G, H-WZ24.

which was enough to destroy the crystal structure of the clay minerals, and, in some cases, it was presumably close to the beginning of vitrification. In rare cases, the temperature was low enough, that the original structure of the unfired ceramic body was preserved.

The aplastic components are represented by the detrital grain of varied fractions (silt plus sand) and mineralogy (Figure 8-11). Quartz is ubiquitous, whereas the feldspars and rock fragments (granitoids and cherts) are subordinates. The accessory components are represented by: muscovite, biotite, hornblende, zircon, rutile. The smaller grains (mostly silt fraction) are sub-angular and angular, whereas the larger grains (mostly sand fraction) are less common and generally sub-rounded or sub-angular.

Modal analysis reveals that the aplastic material concentration (Table 2) is higher in bricks from the octadecagonal building $(36.5 \div 40.0 \mathrm{vol} \%)$ and the octagonal hall $(37.6 \div 40.8 \mathrm{vol} \%)$ with respect to lower values observed in bricks from the brick (first) palace $(22.8 \div 32.0 \mathrm{vol} \%)$ and the fortified wall $(27.2 \div 32.8 \mathrm{vol} \%)$.
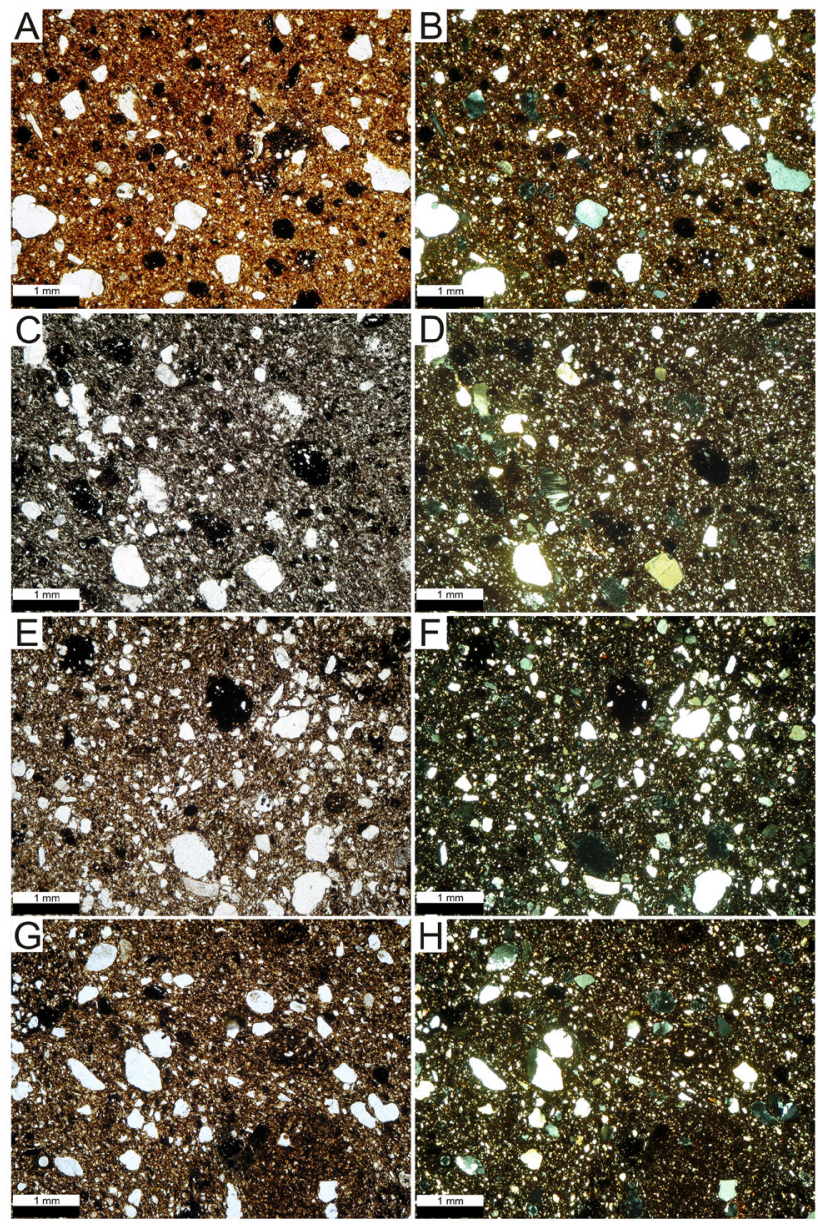

Figure 11. Microphotographs of bricks from the second palace (the octagonal building) in plane-polarised light (left column) and cross-polarised light (right column). Samples: A, B-WZ32; C, D-WZ33, E, F-WZ34, G, H-WZ35.

The grain-size distribution of the aplastic material shows, that the silt fraction $(0.004-0.062 \mathrm{~mm}$ ) prevails (Figure 14), ranging from 84 to $96 \%$. It is strongly dominated by quartz, accessories and feldspars are less common. Lithic grains are absent within this fraction. Sand fraction $(0.062-2.00 \mathrm{~mm})$ constitutes a minor part of the aplastic material (Figure 14), ranging from 4 to $16 \%$. This fraction is noticeably enriched in the feldspars, it contains lithic grains, but is free from accessories. The difference between the studied bricks lies mostly in the abundance of the very fine silt (Figure 15). The bricks from the octadecagonal brick building have lower proportions of a very fine silt $(0.004-0.008 \mathrm{~mm})$, whereas those from the so-called 'second palace' are enriched in this fraction (Figure 15). The fine sand fraction also varies from one sample to another. In most cases, it does not exceed $1.5 \%$ (Figure 14A, B, C), however, bricks from the 'second palace' (Figure 14D) contain up to $4.2 \%$ grains of this fraction.

It is a great challenge to distinguish between the aplastic particles occurring naturally in clay, and the aplastic material (i.e. temper) 


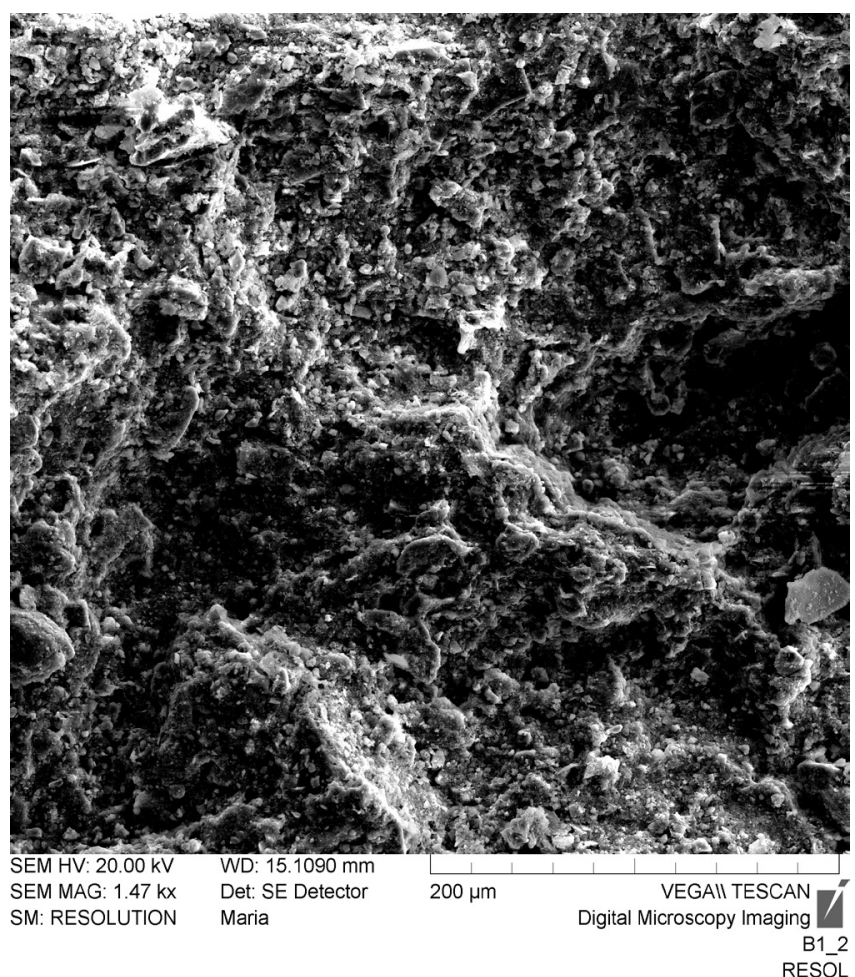

Figure 12. Secondary electron images of brick WZ12.

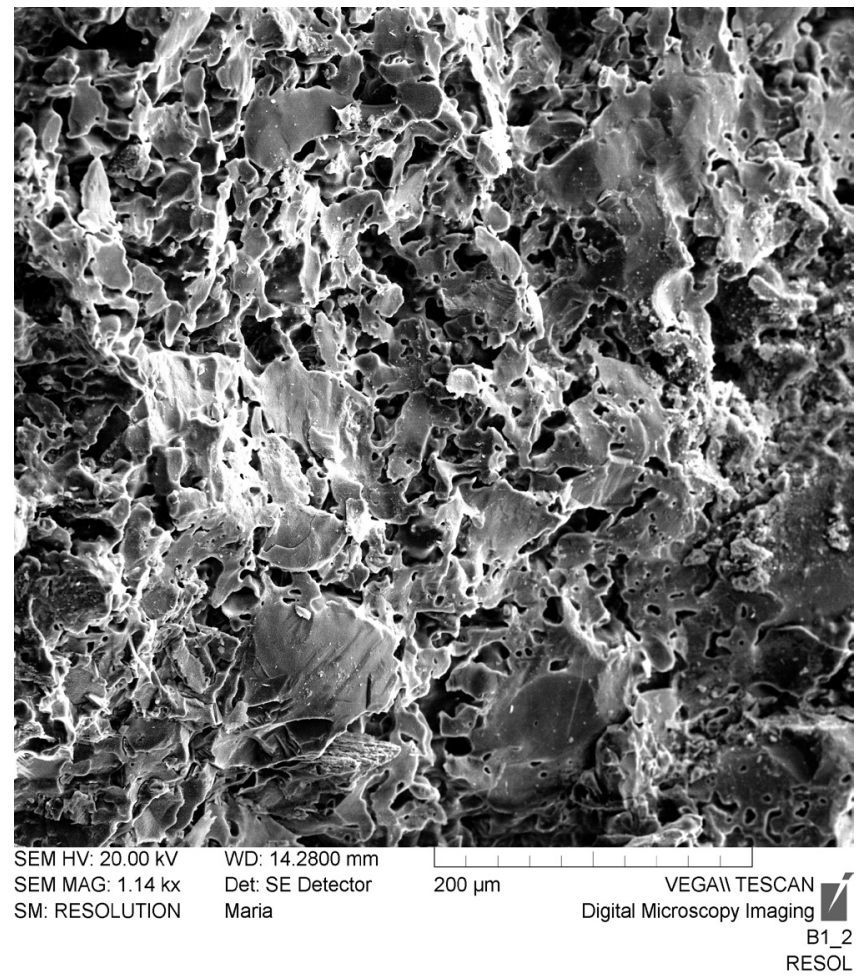

Figure 13. Secondary electron images of brick WZ21.

ceramic, carbonates decompose above $600^{\circ} \mathrm{C}$ and react with the fired clays to form new calcium silicate phases, such as gehlenite, anorthite, diopside, wollastonite or mullite (Cardiano et al., 2004; Cultrone et al., 2005; Özkaya \& Böke, 2009; Sağın \& Böke, 2013). In case of the Ca-poor ceramic, low amounts of fluxes hinder the formation of new phases and the original mineralogy of the raw material is mainly preserved (Moropoulou et al., 1995; Cardiano et al., 2004).

PXRD results showed different mineralogical and phase contents. All the investigated samples (Figure 16) showed the most intense peaks at the quartz position. The feldspars (plagioclase and microcline) occur, but with different abundance. Strong peaks are well visible for most of the bricks, but sample WZ21 shows only traces of this constituent. Obviously, all of these minerals are components of the aplastic material. Most of the samples do not include clay minerals, but a peak at $5.02 \AA \AA$ and a less intense peak at 10.00 $\AA ̊$ (sample WZ12) could be attributed to illite (/muscovite). Hematite (peaks at: $d=2.70 ; 3.67$ ) is a crystalline phase common for most of the samples, except for sample WZ21. Cristobalite, with its most intense peak at $4.13 \AA$ is an uncommon phase, detected only for samples WZ1 and WZ21. A peak at approximately $2.5 \AA$ presumably corresponds to a peak of hematite $(2.53 \AA)$ or results from the overlapping of peaks assigned to hematite and cristobalite (in samples WZ1 and WZ21). A small peak at $3.39 \AA$ (sample WZ21), partly overlapping with the quartz peak, may suggest the presence of mullite ( $3.39 \AA, I=100)$. On the other hand, its pres- 

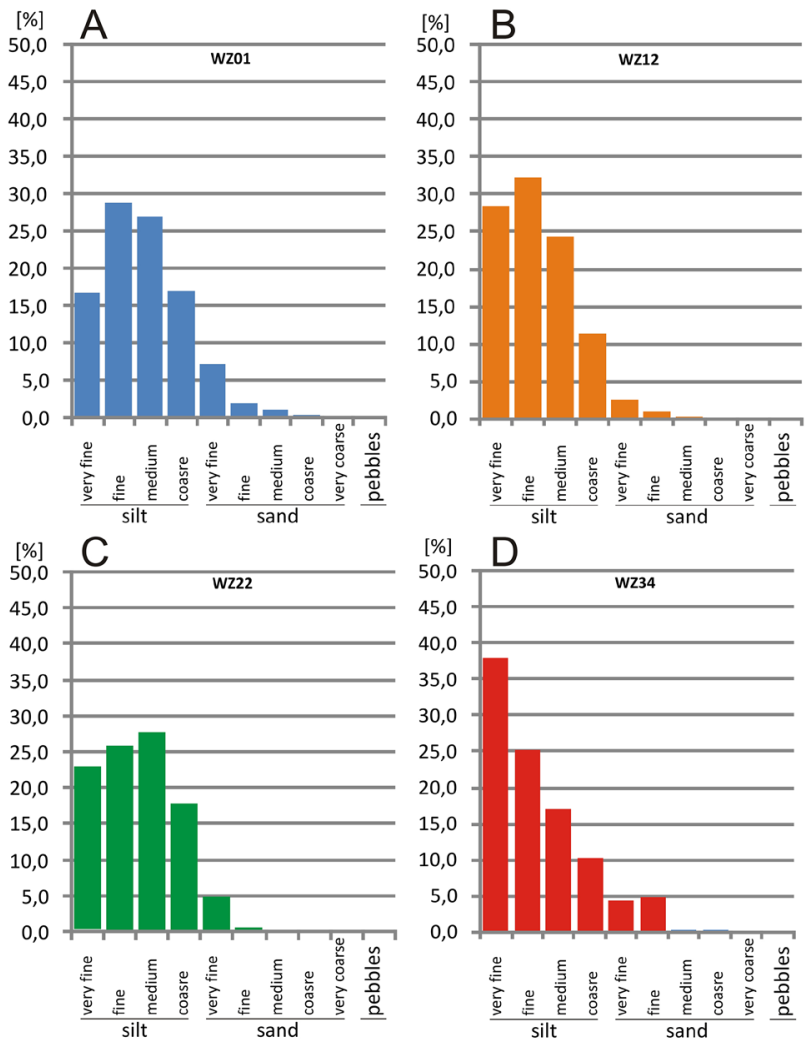

Figure 14. Representative histograms of the grain-size distribution of aplastic materials. A-sample WZ01 (the octadecagonal building), B-sample WZ12 (the brick palace), C-sample WZ22 (the fortified wall), D-sample WZ34 (the octagonal hall).

ence is questionable, since there are no other intense peaks at $3.43 \AA$, $(I=95)$ and $2.20 \AA(I=60)$.

It is known from numerous analytical and experimental works, that illite breaks down in the range $900-1000^{\circ} \mathrm{C}$ (López-Arce et al., 2003; İssi et al., 2011). Moreover, its reflections decrease with an increase in the firing temperature. Its basal reflection $001(\mathrm{~d}=$ $10.00 \AA)$ is particularly sensitive, whereas the reflection $110(\mathrm{~d}=$ $4.48 \AA$ ) is not essentially affected below $900-950^{\circ} \mathrm{C}$ (Rathossi et al., 2004). Illite peaks were detected only in brick WZ12. Thus, we can conclude, that in this particular case, the firing temperature did not exceed $900^{\circ} \mathrm{C}$. The occurrence of hematite is another point of reference. It forms at approximately $800^{\circ} \mathrm{C}$ (Maritan et al., 2006) or at $850^{\circ} \mathrm{C}$ in the Ca-poor clays (Cardiano et al., 2004, Sağın \& Böke, 2013). Manoharan et al., (2011) claim that hematite could be formed after exceeding the temperature of $750^{\circ} \mathrm{C}$. Therefore, we can state that the temperature of firing of brick WZ12 was below this value, whereas all remaining samples recorded a temperature above $750^{\circ} \mathrm{C}$. The occurrence of cristobalite seems very important for our temperature evaluation. According to Sağın and Böke (2013) a high temperature modification of silica could be formed at $800^{\circ} \mathrm{C}$. In fact, the topology of the phase diagram of silica gives a higher value of $873^{\circ} \mathrm{C}$ when the beta-cristobalite is

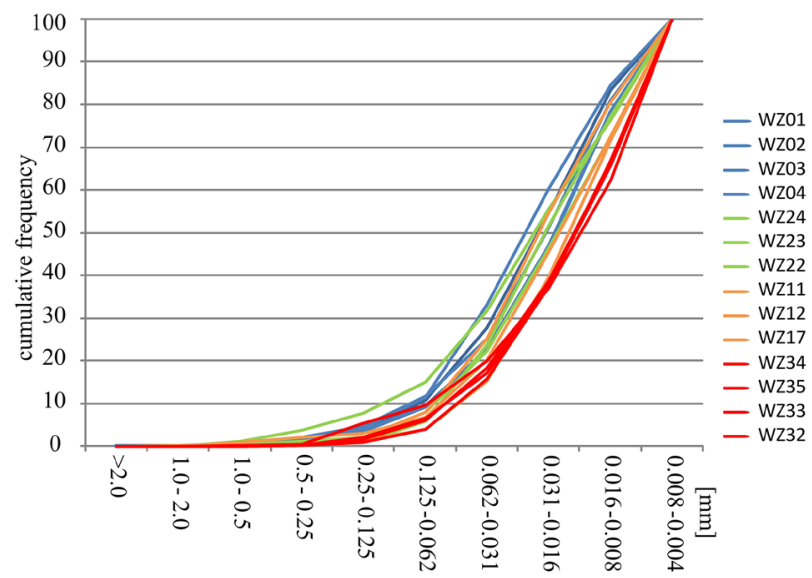

Figure 15. Cumulative curves of the grain-size distribution of aplastic material. Blue curves-bricks from the octadecagonal building, orange curves-bricks from the brick palace, green curves-bricks from the fortified wall, red curvesbricks from the octagonal hall.

stable (Kraner, 1970). This high temperature silica form remains as a metastable form when the brick is cooled down from the baking temperature to the room temperature (Kraner, 1970). Bearing in mind those relationships, we might expect that bricks WZ1 and WZ21 were fired above $873^{\circ} \mathrm{C}$. The temperature stays in good agreement with the strongly reduced intensity of the feldspar peaks in sample WZ21. Manoharan et al. (2011) noticed, that during an experimental firing of alluvial clays, reflections of the feldspars disappear above the temperature of approximately $900^{\circ} \mathrm{C}$ or slightly higher, at $950^{\circ} \mathrm{C}$ (Palanivel \& Kumar, 2011). Another high temperature phase detected in the studied bricks is mullite. Its presence in sample WZ21 confirms that this particular brick was subjected to a very strong thermal treatment, since this phase forms at a temperature of no less than $900^{\circ} \mathrm{C}$ (Cultrone et al., 2005; Scalenghe et al., 2015), or even $950^{\circ} \mathrm{C}$ (Molera et al., 1998).

DSC-TG diagrams show similar curves, with a relatively small total weight loss at $990^{\circ} \mathrm{C}$ (Figure 17; Table 3), ranging from $0.6 \mathrm{wt} . \%$ (sample WZ11) to 1.9 wt. \% (sample WZ12). All the diagrams are characterised by two or three well pronounced weight losses. Less common are the thermograms, with additional one or two DTG curve inflections, corresponding to minor amount of weight loss. One of the main DTG curve inflections appears in the range $610-692^{\circ} \mathrm{C}$ (Table 3) and could be interpreted as a thermal decomposition of calcite (Sağın \& Böke, 2013; Földvári, 2011), but PXRD charts do not confirm the occurrence of this phase. Thus, this effect presumably corresponds to the dehydroxylation of clay minerals. Another important weight loss falls into the wide range between $150-500^{\circ} \mathrm{C}$ (Table 3), with inflection centred at different temperatures (from 232 to $402^{\circ} \mathrm{C}$ ), depending on the sample. Maritan et al. (2006) explained such effect as the removal of hygroscopic water from illite, but in our opinion, this is a result of the dehydroxylation of a small amount of goethite or lepido- 


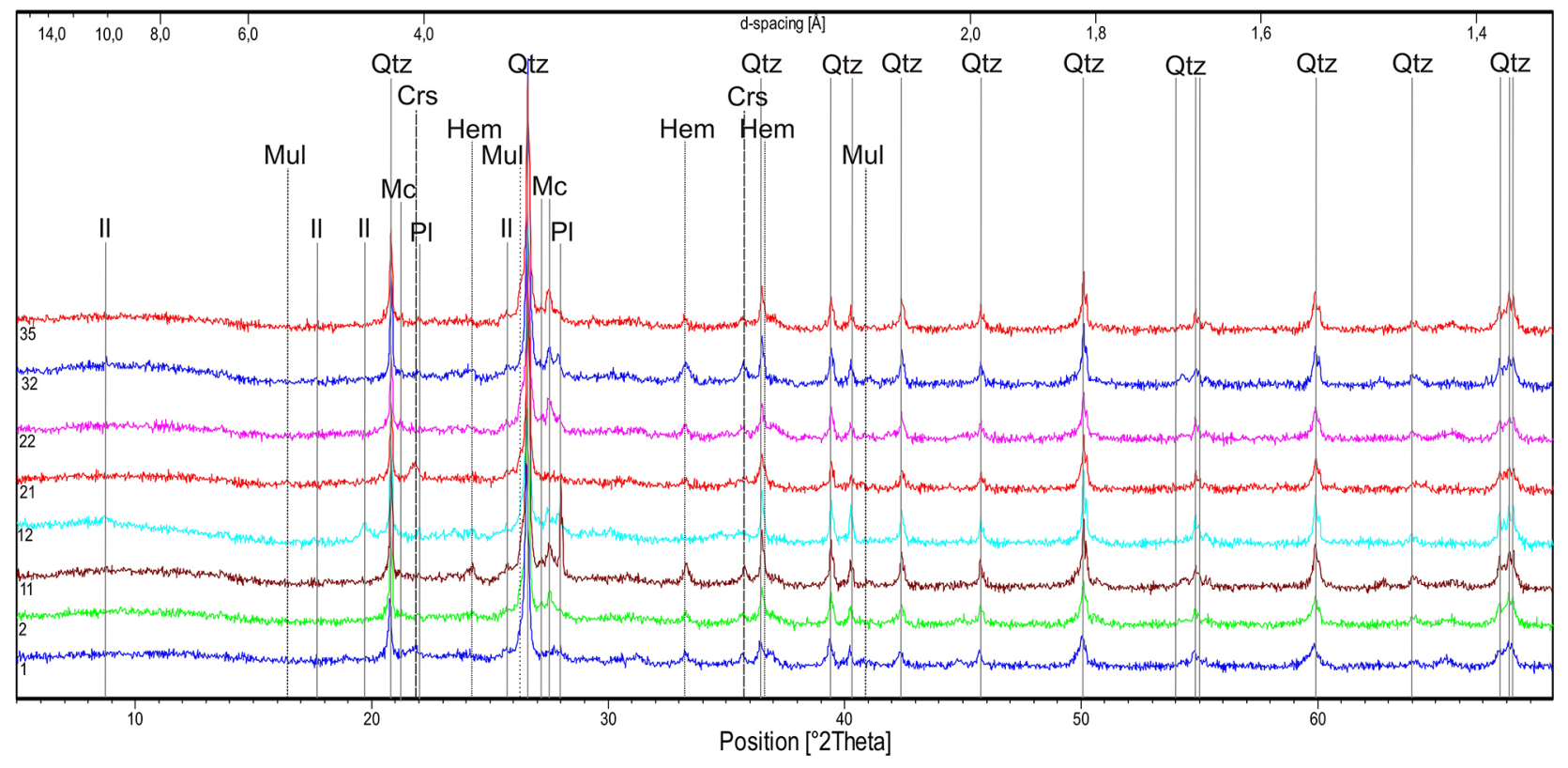

Figure 16. Powder XRD patterns of examined bricks. Qtz-quartz, Crs-cristobalite, Hem-hematite, Mul-mullite, Mc-microcline, Pl-plagioclase, II-illite.

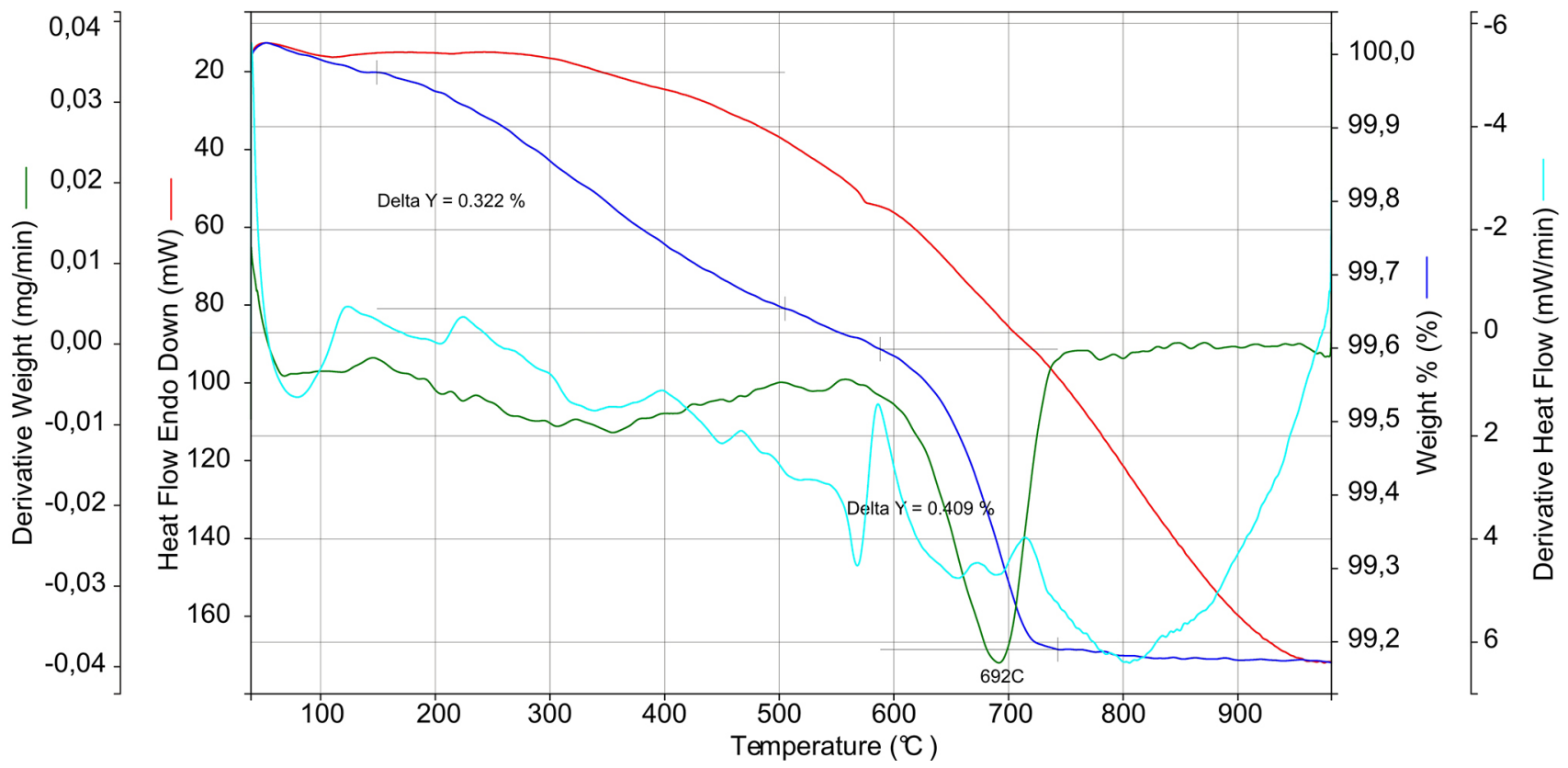

Figure 17. Representative DSC-TG scan of sample WZ21.

crocite, since their peak of dissociation typically lies at $290-330^{\circ} \mathrm{C}$ (Földvári, 2011). DCS-TG diagrams show an additional small endothermic effect associated with weight loss (peak in the range of $112-119^{\circ} \mathrm{C}$; Table 3 ) due to the removal of adsorbed and interlayered water (dehydratation of clay minerals, Földvári, 2011). Some of the authors (Cardiano et al., 2004) claim, that clay min- erals fired below $800^{\circ} \mathrm{C}$ tend to slowly rehydroxylate. Therefore, such explanation seems to be acceptable.

A very small total weight loss indicates, that the raw materials of bricks were strongly dehydroxylated during firing. Since all of the bricks exhibit a similar proportion of plastic and aplastic constituents, it can be assumed that the differences in total weight 
Table 3. Results of the DSC-TG analysis.

\begin{tabular}{c|c|c}
\hline Sample & $\begin{array}{c}\text { Total weight loss [wt. \%] } \\
\text { (in range } \mathbf{4 0} \text { to } 990^{\circ} \mathrm{C} \text { ) }\end{array}$ & $\begin{array}{c}\text { Detected weight loss [wt. \%] - and } \\
\text { associated peak temperature }\end{array}$ \\
\hline WZ1 & 1.08 & $0.57-326^{\circ} \mathrm{C}$ \\
& & $0.31-678^{\circ} \mathrm{C}$ \\
\hline WZ2 & 1.04 & $0.03-119^{\circ} \mathrm{C}$ \\
& & $0.69-300^{\circ} \mathrm{C}$ \\
& & $0.12-572^{\circ} \mathrm{C}$ \\
& & $0.19-644^{\circ} \mathrm{C}$ \\
\hline WZ11 & 0.64 & $0.02-112^{\circ} \mathrm{C}$ \\
& & $0.43-234^{\circ} \mathrm{C}$ \\
& & $0.09-610^{\circ} \mathrm{C}$ \\
\hline WZ12 & 1.92 & $0.90-92^{\circ} \mathrm{C}$ \\
& & $0.39-220^{\circ} \mathrm{C}$ \\
& & $0.49-402^{\circ} \mathrm{C}$ \\
WZ21 & 0.82 & $0.29-650^{\circ} \mathrm{C}$ \\
& & $0.32-330^{\circ} \mathrm{C}$ \\
WZ22 & 1.12 & $0.41-692^{\circ} \mathrm{C}$ \\
& & $0.60-245^{\circ} \mathrm{C}$ \\
WZ32 & 0.86 & $0.30-677^{\circ} \mathrm{C}$ \\
& & $0.05-112^{\circ} \mathrm{C}$ \\
& & $0.66-232^{\circ} \mathrm{C}$ \\
& & $0.13-648^{\circ} \mathrm{C}$ \\
\hline WZ35 & 1.32 & $0.11-112^{\circ} \mathrm{C}$ \\
& & $0.57-238^{\circ} \mathrm{C}$ \\
& & $0.43-670^{\circ} \mathrm{C}$ \\
\hline
\end{tabular}

loss point to a different degree of destruction of the clay minerals structure and, thus, to a different firing temperature and/or residence time in the kiln. Therefore, the bricks with the lowest total weight (i.e. WZ11 and WZ21) were presumably fired at the highest temperature, compared to those with a higher weight loss (i.e. WZ12, WZ35), baked at relatively lower temperatures.

On the basis of the PXRD and DSC-TG results, we conclude that almost all of the studied bricks, sampled from different construction phases, are characterised by a relatively high temperature of firing (Table 4). In most cases, the bricks are strongly fired, at temperatures of at least $850-900^{\circ} \mathrm{C}$. Only few of the bricks underwent baking at a low temperature, not exceeding $750^{\circ} \mathrm{C}$. Rare bricks were also fired at a higher temperature, reaching at least $950^{\circ} \mathrm{C}$.

\subsection{Provenance of raw materials for brick production}

At the current stage of our research, despite the described differentiations in the aplastic components, we cannot say much about the source of raw materials used for the production of studied bricks and their chemistry. However, on the basis of the inferred temperature of firing and the detected mineral assemblage we can presume, that the lack of high temperature calcium-rich phases points out to a low-Ca ceramic. Furthermore, some information could be deduced from the analysis of the local geological settings. In the nearest vicinity of Wrocław, the deep Proterozoic crystalline basement is covered with younger rocks, ranging in age from the Carboniferous period to the Cretaceous period (Kłapciński, 1993). These rocks are overlaid with a continuous Cenozoic cover (Kłapciński, 1993; Goldsztejn, 2009). The oldest part
Table 4. Summarized results of PXRD analysis and inferred temperatures of firing.

\begin{tabular}{l|l|l}
\hline Sample & \multicolumn{1}{|c|}{ Minerals/phases } & Temperature \\
\hline WZ1 & quartz, plagioclase, hematite, cristobalite & $850-900^{\circ} \mathrm{C}$ \\
\hline WZ2 & quartz, microcline, hematite & $850-900^{\circ} \mathrm{C}$ \\
\hline WZ11 & quartz, microcline, plagioclase, hematite & $850-900^{\circ} \mathrm{C}$ \\
\hline WZ12 & $\begin{array}{l}\text { quartz, microcline, plagioclase, illite (/muscovite), } \\
\text { hematite }\end{array}$ & $<750^{\circ} \mathrm{C}$ \\
\hline WZ21 & quartz, cristobalite, mullite & $950^{\circ} \mathrm{C}$ \\
\hline WZ22 & quartz, microcline, plagioclase, hematite & $850-900^{\circ} \mathrm{C}$ \\
\hline WZ32 & quartz, microcline, plagioclase, hematite & $850-900^{\circ} \mathrm{C}$ \\
\hline WZ35 & quartz, microcline, plagioclase, hematite & $850-900^{\circ} \mathrm{C}$ \\
\hline
\end{tabular}

of this strata is dominated by the Miocene sands, silts and clays, cropping out in the western part of Wrocław city, in abandoned brickwork quarries (districts: Pilczyce, Stabłowice, Żerniki). This is followed by the coloured clays (the so-called 'flamy clay' horizon) of Miocen-Pliocen age and the Gozdnica series that includes clastic rocks (sands, gravels) intercalated with clays of a variable content of carbonates (Choma-Moryl, 1988). They occur as isolated patches, up to a few metres in thickness (Goldsztejn, 2009). Quaternary glacial deposits, represented by the Sanian-I and Sanian-Il grey, or greyish-brown, sandy loams, rich in carbonates occur above this level (Goldsztejn, 2009). On top of this succession there are sands separated with glacial tills, underlain with greyish and yellowish marly clays (Goldsztejn, 2009). Since the paste used for the fabrication of the examined bricks presents a well sorted material, it seems unlikely that the glacial tills were used. Moreover, the lack of newly formed Ca-bearing phases in bricks stays in contradiction to this idea, since the locally occurring glacial tills are rich in carbonates. On the other hand, 'flamy clays' seem to be a good source of raw material for brick production. They represent silty clays, almost carbonate free (below 1\%), with streaks and patches of iron-oxides (Choma-Moryl, 1988). Similar structures, i.e. brownish patches, are well visible in most of the examined bricks (c.f. 9C, 10C, 11A). The deposits of 'flamy clays' occur relatively shallowly, at the depth of approximately $2 \mathrm{~m}$ below the surface of the ground, therefore they are easily accessible and exposed not so far away from the ducal castle (Żerniki and Stabłowice district, $8 \mathrm{~km}$ far from the ducal castle). Assuming this was the particular source of material, the sandy fraction in the examined bricks would represent temper - perhaps the river sand obtained from the neighbouring Odra river.

\section{Final Remarks}

Our study demonstrates, that there are some clear differences between bricks used for the construction of the ducal castle. Some of these dissimilarities are related to the different construction phases and some are not. Despite the fact, that the examined bricks differ much in colour, they all exhibit similar petrographic 
features. However, well expressed differences, linked to different construction phases, lie in the abundance of accessory minerals and the differentiation of the grain-size distribution of aplastic material. The bricks from the octadecagonal brick building are strongly depleted in the very fine silt, whereas those from the octagonal hall are enriched in this fraction. Typically, accessory minerals are rather uncommon and very small, up to $0.1 \mathrm{~mm}$. On the other hand, the bricks from the brick (first) palace are enriched in micas and hornblende. Furthermore, the crystals of these minerals are noticeably larger, reaching up to $0.5 \mathrm{~mm}$ in diameter, compared to those from bricks representing other construction phases.

This study demonstrates that a detailed petrographic study, in conjunction with a historical research, might be a useful tool in discrimination of construction phases. Our research confirmed the existence of at least four main construction phases. In our case, in contrast with similar studies (Barluenga et al., 2014; López-Arce et al., 2003), the construction phases took place in a relatively short period of time (ca. one century). Moreover, the material was not as strongly diversified as it was known from similar studies described in literature. Yet, it allowed us to assign the examined bricks to different constructing phases. The positive results of the mineralogical studies are of a particular importance in the case of bricks derived from fragments of the ducal castle on Ostrów Tumski, but unassigned to any of the known constructing phases. Thus, future work will be devoted to this kind of historic material, designed for the morphological studies of bricks, and to specify the most accurate source of raw materials for brick production and the determination of their chemical character (Carich or (a-poor).

\section{Acknowledgements}

The research was financed by the National Science Centre in Poland, (DEC-2012/05/B/HS3/03704).

\section{References}

[1] Barluenga G., Estirado F., Undurraga R., Conde J.F., Agua F., Villegas M. Á., García-Heras M. 2014. Brick masonry identification in a complex historic building, the Main College of the University of Alcalá, Madrid (Spain). Constr. Build. Mater., 54: 39-46.

[2] Caban M. 2015. 'Porównawcze badania pomiarowe cegieł z kościoła Salwatora we Wrocławiu' [in:] Wachowski, K. (ed.) Cmentarz Salwatora: pierwsza nekropolia wrocławskich protestantów, Wratislavia Antiqua: studia z dziejów Wrocławia/Zespół do Badań Średniowiecznego i Nowożytnego Wrocławia, 21, 197-213, Uniwersytet Wrocławski, Instytut Archeologii, Wrocław.

[3] Cardiano P., loppolo S., De Stefano C., Pettignano A., Sergi S., Piraino, P. 2004. Study and characterization of the ancient bricks of monastery of "San Filippo di Fragalà" in Frazzanò (Sicily). Anal. Chim. Acta., 519: 103-111.

[4] Choma-Moryl K. 1988. Variability of physical properties of the Poznan Clays (Neogene) from the area of Wroclaw, with reference to their genesis and Lithostratigraphy. Geologia Sudetica, XXIII (1): 1-63.

[5] Cultrone G., Sidraba I., Sebastián E. 2005. Mineralogical and physical characterization of the bricks used in the construction of the "Triangul Bastion", Riga (Latvia). Appl. Clay. Sci., 28: 297-308.

[6] Földvári M. 2011. Handbook of Thermogravimetric System of Minerals and Its Use in Geological Practice, Geological Institute of Hungary, Budapest.

[7] Goldsztejn J. 2009. Baza danych geologiczno-inżynierskich wraz z opracowaniem atlasu geologiczno- inżynierskiego aglomeracji wrocławskiej, [w] https://www.mos.gov.pl/g2/big/2009_09/ a8a2d170e5086c8c2b2b8fc705d9d161.pdf (accessed: 11.11.2015).

[8] Gredmaier L., Banks C.J., Pearce R.B. 2011. Calcium and sulphur distribution in fired clay brick in the presence of a black reduction core using micro X-ray fluorescence mapping. Constr. Build. Mater., 25: 4477-4486.

[9] Grzybkowski A. 1994. O wrocławskich kaplicach zamkowych. Kwartalnik Architektury i Urbanistyki, 49 (3): 221-230.

[10] İssi A., Kara A., Alp A.O. 2011. An investigation of Hellenistic period pottery production technology from Harabebezikan/Turkey. Ceram. Int., 37: 2575-2582.
[11] Kłapciński J. 1993. Litostratygrafia profili głębokich otworów wiertniczych $w$ regionie opolskim, Acta Universitatis Wratislaviensis. Prace Geologiczno-Mineralogiczne 37. Wydawnictwo Uniwersytetu Wrocławskiego, Wrocław.

[12] Kraner H.M. 1970. The Use of Phase Diagrams in the Development and Use of Refractories. [in:] Alper A.M. (ed.) Phase Diagrams, 67-115, Academic Press, New York.

[13] López-Arce P., Garcia-Guinea J., Gracia M., Obis J. 2003. Bricks in historical buildings of Toledo City: characterisation and restoration. $\mathrm{Ma}$ ter. Charact., 50: 59-68.

[14] Małachowicz E. 1994. Wrocławski zamek książęcy i kolegiata św. Krzyża na Ostrowie, Wydawnictwo Politechniki Wrocławskiej, Wrocław.

[15] Małachowicz E., Lasota C. 1989. Opactwo Św. Marcina na zamku wrocławskim na Ostrowie. Kwartalnik Architektury i Urbanistyki : teoria i historia, 34 (1-2): 3-18.

[16] Manoharan C., Sutharsan P., Dhanapandian S., Venkatachalapathy R., Asanulla R.M. 2011. Analysis of temperature effect on ceramic brick production from alluvial deposits, Tamilnadu, India. Appl. Clay Sci., 54: 20-25.

[17] Maritan L., Nodari L., Mazzoli C., Milano A., Russo U. 2006. Influence of firing conditions on ceramic products: Experimental study on clay rich in organic matter. Appl. Clay. Sci., 31: 1-15.

[18] Molera J., Pradell T., Vendrell-Saz M. 1998. The colours of Ca-rich ceramic pastes: origin and characterization. Appl. Clay. Sci., 13: 187-202.

[19] Moropoulou A., Bakolas A., Bisbikou K. 1995. Thermal analysis as a method of characterizing ancient ceramic technologies. Thermochim. Acta., 269-270: 743-753.

[20] Özkaya Ö., Böke H. 2009. Properties of Roman bricks and mortars used in Serapis temple in the city of Pergamon. Mater. Charact., 60: 995-1000.Palanivel R., Kumar U.R. 2011. Thermal and spectroscopic analysis of ancient potteries. Rom. J. Phys., 56 (1-2): 195-208.

[21] Rathossi C., Tsolis-Katagas P., Katagas C. 2004. Technology and composition of Roman pottery in northwestern Peloponnese, Greece. Appl. Clay. Sci., 24: 313-326. 
[22] Roduit N. 2007. JMicroVision: un logiciel d'analyse d'images pétrographiques polyvalent. http://www.jmicrovision.com (on-line, accessed: 03 February 2015).

[23] Sağın E., Böke H. 2013. Characteristics of bricks used in the domes of some historic bath buildings. J. Cult. Herit., 14 (3): e73-e76.

[24] Scalenghe R., Barello F., Saiano F., Ferrara E., Fontaine C., Caner L., Olivetti E., Boni I., Petit S. 2015. Material sources of the Roman brickmaking industry in the I and II century A.D. from Regio IX, Regio XI and Alpes Cottiae. Quat. Int., 357: 189-206.

[25] Żurek A. 1996. Wrocławska kaplica św. Marcina w średniowieczu, Uniwersytet Wrocławski, Centrum Badań Śląskoznawczych i Bohemistycznych, Wrocław. 